\title{
Investigating the Role of English Language as International Medium for Learning Medical Sciences
}

\author{
Abdelrahman Elyass Mohamed Abdelmajd \\ University of Khartoum - Faculty of Arts, Sudan \\ e-mail:elyass572003@yahoo.com \\ Hassan Mahill Abdallah Hassan \\ Sudan University of Science \&Technology - College of Education, Sudan \\ e-mail:mahill74@yahoo.com
}

\begin{abstract}
This paper aims to answer "To what extent English Language as International Medium can help for Learning Medical Sciences?" The researcher has adopted the quantitative method as well as the questionnaire as a tool for collecting data relevant to the study to bring to the light the importance of English Language as International Medium for Learning Medical Sciences. The sample of this study comprises (60) students. The marks obtained from the questionnaire were compared. From one hand, the results have revealed that the students encountered difficulties in understanding the Medical Sciences. The result has shown that the questionnaire significance indicates that there is highly difference among students. Therefore, this indicates that English Language as International Medium can play a great role for Learning Medical Sciences. Keywords: LSP, ESP, EMP
\end{abstract}




\section{INTRODUCTION}

English has become as International Language Medium for Learning Medical Sciences. This is due to the fact that the recent technological expansion in the developed countries has brought about new fields, areas of technology, along with the terminology associated with them. Medicine is no exception, developed countries constantly investing large sums of money into research, hence the unprecedented advancement and progress in the field of health sciences.

For a great number of researchers and doctors who write biomedical articles, English may not be the mother tongue. Consequently, to have their articles published in renowned, high impact factor journals, medical researchers turn to translators. Nevertheless, translators are not professionals in health sciences and rely on different strategies and solutions in dealing with the problems they encounter. Problems are of various types but they can be categorised into terminological, linguistic and extra linguistic.

\subsection{Aims and Scope of the Study}

This study aims to investigate the Role of English Language as International Medium for Learning Medical Sciences. The scope of the study is limited to the second class students of Medical Science at Khartoum College for Medical Sciences-2007-2008. There are (60) second class students of Medical Science at Khartoum College for Medical Sciences.

\section{LITERATURE REVIEW}

\subsection{Languages for Specific Purposes (LSPs)}

Specialized languages usually refer to the specific discourse used by professionals and specialists to communicate and transfer information and knowledge. There are as many specialised languages as there are professions. That is what has usually been known as Languages for Specific Purposes or, when applied to English, English for Specific Purposes (ESP), i.e., the special discourse used in specific settings by people sharing common purposes. Occupational registers provide an efficient code for the transfer of information among specialists, because they provide a practical and convenient shorthand for talking about complex matters specific to a field.

\subsection{English for Specific Purposes (ESP)}

The relevance of English in academic and professional settings began some decades ago, in the 1960s, and it has not decreased. Orr (2002:1) said that ESP "is an exciting movement in English language education that is opening up rich opportunities for English teachers and researchers in new professional domains". Following Ypsilandis and Kantaridou (2007:69), English for Academic Purposes (EAP) "refers mainly to the academic needs of students and of future professionals who would seek a career in the academic environment" and English for Professional Purposes (EPP) refers to "the actual needs of (future) professionals at work". These two broad fields or categories also involve many different areas and fields of interest and research. Dudley-Evans and St John (1998:19) said that "ESP is essentially a 
materials- and teaching-led movement" closely interlinked with Applied Linguistics and English Language Teaching. When looking deeper into the research trends or approaches in ESP, they refer especially to register analysis, rhetorical and discourse analysis, analysis of study skills, and analysis of learning needs (Ruiz-Garrido, Palmer-Silveira and Fortanet-Gómez, 2010:1-2).

For most of its history, English for Specific Purposes (ESP) has been dominated by English for Academic Purposes (EAP), and by the subspecialty English for Science and Technology (EST) (Swales, 1988); EAP continues to dominate internationally (Johns and Dudley-Evans, 1993:124). EAP and ESP are now commonly referred to as International Scientific English (ISE). The common feature of this discourse community is the skilful use of English to write science. Scientific research, not language, is the focus and this has interesting consequences for the teaching of EST. If English is seen as ISE, it forms part of science, and is therefore also an integral part of 'becoming a scientist' nowadays (Wood, 2001:81$83)$.

\subsection{Language or Languages of Medicine?}

Medical language is the occupational register of physicians and it is largely opaque outside the medical community. Several authors have commented on one particular feature of medical language. McCullough (1989) and Mintz (1992) see medical language as an abstract discourse about disease and organs and emphasize its distancing function, an artifact of its commitment to objectivity. Crookshank (1923), Cassell (1976), Warner (1976) and Fleischman (1999) have commented on the lexicalization of diseases as static entities rather than dynamic processes (Fleischman, 2003:475).

The English language, with scientific and professional development, is no longer a foreign language for other nations, but it has become a mother tongue, it is linguafranca, which used to be Latin once upon a time. English has become the lingua franca of medicine and most scientific fields since $95 \%$ of medical papers come from English speaking countries (Pilegaard, 2000:7).

\subsection{Huge Development of Medicine}

In the past two centuries epochal discoveries have been made in natural sciences,particularly medicine which takes a special place since it has been as old as mankind. The new branches of fundamental medical science such as molecular biology, genetics and biomedicine have become the foundation of understanding and interpreting medicine. These disciplines have been followed by numerous clinical subdisciplines. It means that the medical science returned to the cellular level and, for the first time, scientists discovered genetic structure of the human genome, which made possible cloning of the human being. Furthermore, we are witnessing the appearance of new parasitic and viral diseases (virus synthesis was made - polio) caused by prions (SARS - severe acute respiratory syndrome, mad cow disease, avian flu, and the latest deadly form of flu caused by H1N1 virus). Finally, the most prominent has been a huge progress of modern technology and its application in medicine (electron microscope, computer, scanner, magnetic resonance imaging, 
ultrasound and others). The most recent trend is related to nanotechnology which implies creating machines of very minute dimensions, the size of a molecule (a nanometre is one thousand millionth of a metre!) In not so near future, it seems that those machines called nanorobots will be used in treatment (destroying viruses or cancer cells, recovering damaged cells and tissues) as well as in control of the ageing process.

\subsection{English for Medical Purposes (EMP) - Present}

Such huge development of medical science and practice requires further improvement of the language of medicine. It has become necessary to create new terms not only for new illnesses and disorders but a totally new terminology for fundamental medical branches, particularly terms for state-of-the-art technology. It has been shown that the language of medicine finds it hard to keep pace with medical science and practice. It frequently describes rather than defines incompletely understood natural phenomena. Modern medicine has transgressed the boundaries of the Greco-Latin terms andmust create a new terminology (Mićić, 2009a:231-234).

Jammal (1988) comments that science flies and its terminology walks typically at a pace that lags far behind scientific advances. New disease names emerge, and changes are observed in the meanings of established disease names. Medicine is so highly compartmentalized that, for example, one's background in surgery and emergency medicine offers little help when one is faced with a dermatology translation. This makes research crucial (O’Neill, 1998:76).

The English language of medicine has been understood well and extensively studied. It serves as a model for other nations how to create their languages of medicine. The Greco-Latin basis of terms is but one feature of the language of medicine, which, in the case of English, manifests a special preference for synonym, eponym, acronym and abbreviation use (myopia, shortsightedness; Parkinsonism; laser; AIDS). There are a number of forms specific for the English language of medicine. There is a very precise and elaborate popular terminology related to illnesses (apart from the technical Greco-Latin term herpes zoster, there is a native English word shingles). Thus there is a tendency to use a descriptive term taken from everyday language rather than a learned expression (clotting rather than coagulation). Also, ordinary words with medical meaning are more frequently used (growth for tumour or temperature for fever).

Such words are termed semi-technical words (Trimble, 1985:129). In clinical medicine there are a number of technical idiosyncratic phrases which in the context of everyday speech and writing sound, to put it mildly, strange (The patient presented with jaundice). Last but not least, in the English language of medicine there are noun strings plus necessary adjectives (less often verbs and adverbs) forming a concept with a "single noun" idea (nominal compounds) (NCs). The English language of medicine is full of such compounds (Mićić, 2011:535). 


\subsection{Features of Scientific Texts}

According to Parkinson (2000: 371), scientific texts are characterized by the following features:

1. Nominalization of verbs and adjectives, e.g. A preoccupation with minor indiscretions

2. from the past often occurs in such patients.

3. Technical phrases (medical jargon), e.g. The patient presented with jaundice.

4. Extended nominal groups/collocations, e.g. small middle meatal polyps

5. Tentative language (hedging), e.g. Reduced attachment in the face of polymorph

6. infiltration might indirectly reflect aspects of the immune response...

7. Causal and reasoning verbs, e.g. Addiction is caused by heroin.

8. Impersonal language and passivisation, e.g. The epidermis is molded over the

9. papillae of the dermis.

\subsection{Grammatical and Syntactic Features of English for Medical Purposes (EMP)}

Among grammatical and syntactic features of EMP, the following may be singled out:

1. Reporting verbs, e.g. The patient reported severe side-effects.

2. Non-temporal use of Tenses (Present, Past mostly), e.g. He goes to hospital tomorrow.

3. Passive, e.g. It should be noted that phase-contrast microscopy is not useful with

4. fixed and stained material.

5. Modals, e.g. It must have been Tuesday when she went to the doctor's.

6. Conditional expressions, e.g. If she falls over, she'll hurt herself.

\subsection{Semantic (lexical) Features of EMP}

Greek and Latin are still the basis for medical terminology (Mc Morrow, 1998:14) because they are precise and internationally comprehensible (Berghammer 2006, 40). The most systematic continuing use of medical Greek and Latin is in the official Nomina Anatomica (anatomical terms, abbreviated NA), a standardized list of anatomical terms. Greek- and Latin-based terms can be analysed from prefixes, roots and suffixes so that the meaning is readily understood (for instance, "ultramicrotomy":"ultra" = excess, beyond; "micro" = minute, small; "tomy" = cutting (hence, "the technique of cutting into very thin pieces") (Tables 1, 2 and 3).

$\begin{array}{cll}\text { Table 1. Latin } & \text { English } & \text { Serbian } \\ \text { - laryngitis,-tidis,f. } & \text { laryngitis } & \text { laringitis } \\ \text { - herpes,-etis,m. } & \text { herpes } & \text { herpes } \\ \text { - discus,-i,m. } & \text { disc } & \text { diskus } \\ \text { - paralysis,-is,f. } & \text { paralysis } & \text { paraliza } \\ \text { - sinus,-us,m. } & \text { sinus } & \text { sinus } \\ \text { - anaemia,-ae,f. } & \text { anaemia } & \text { anemija } \\ \text { - nervus,-i,m. } & \text { nervus } & \text { nerv } \\ \text { - asthma,-atis,n. } & \text { asthma } & \text { astma }\end{array}$


- polypus,-i,m. polyp polip

- carcinoma,-atis,n. carcinoma karcinom

- cancer,-i,m. cancer kancer

- libido,-dinis,f. libido libido

- nephritis,-tidis,f. nephritis nefritis

\section{Table 2. Latin English Serbian}

Some English medical terms with Greco-Latin basis and their Serbian popular equivalents:

- atrium,-ii,n. atrium pretkomora

- cicatrix,-icis,f. cicatrix ožiljak

- uterus, -i, m. uterus materica

\section{Table 3. Latin English Serbian}

Some English and Serbian medical terms with parallel Greco-Latin forms: uterus, -i,m. uterus/womb materica manus,-us,f. manus/ hand ruka (but: manuelni) dens,-entis,m. dens/tooth zub (but: dentografija) diarrhea,-ae,f. diarrhea/lientery proliv (but: dijareja)

Source: Mićić, Marković 2011, 840-841

In ESP/ISE, differences are made between terms or specialist vocabulary and semi-technical, subtechnical, context-independent academic words that occur with high frequency across disciplines (Jordan, 1997:152). Words can have special meanings in specific fields, or one or more 'general' English meanings, or have an extended meaning in specific fields (Trimble, 1985:129). Students must be aware of the difference between sub-medical and proper medical terminology because the choice depends on the audience (Wakabayashi, 1996: 360). Coxhead and Nation write about four categories: high frequency words; the academic vocabulary (subtechnical vocabulary); technical vocabulary; and low frequency words (Coxhead and Nation, 2001: 252). Terms are often cognate with the equivalent term in the students' first language and pose only pronunciation difficulties ("diagnosis" = dijagnoza, or "pneumonia" = pneumonija). Non-cognate terms, especially subtechnical concepts, need explanation and a different pedagogical approach ("history" = anamneza, or "strain" = naprezanje). English has a synonym in everyday speech for many medical terms, such as "hemorrhage/bleeding"or "myopia/shortsightedness". The choice of word depends on the audience.

The third lexical feature of ESP/ISE are noun strings plus necessary adjectives (less often verbs and adverbs) forming a concept with a "single noun" idea (compounds or collocations). The English language of medicine is full of such compounds. The fast growth of scientific knowledge in the past half century has generated many new terms, particularly multiterm words, such as "chronic obstructive pulmonary disease" (Berghammer, 2006: 42). Attempts to translate compounds into a language that does not compound usually result in long and unwieldy phrases (Trimble, 1985: 130-131). Examples: "gonadotropin-releasing 
hormone" = hormon koji oslobadja gonadotropin, "arsenic-fast virus" = virus rezistentan na arsenik (Micic, 2008:174). It is via collocations that the realization of the term is achieved (Hauenherm, 1998: 150). Collocation is the way words combine in a language to produce natural-sounding speech and writing. It takes a greater degree of competence with the language to combine words correctly in productive use. To a native speaker these combinations are highly predictable; to a learner they are anything but collocations are very important in the language of medicine and were the topic of our studies on contrastive analysis of terms for illnesses and disorders in English and Serbian. All terms for illnesses and disorders have been classified into 23 groups according to the features related to the nature of illness. Those features are adjectival-nominal syntagms - collocations, extended by the addition of verbs. It has been concluded that the basic terms are 'illness' and 'disorder' in English, and 'bolest' and 'poremećaj' in Serbian. However, English has more terms to offer for 'illness': 'disease', 'condition', 'sickness', 'complaint'. By combining these basic terms with adjectives and verbs, deep insights into the nature of terms have been obtained.

There are two interesting cases worth mentioning: sickness and fever. In one sense, they both represent symptoms: nausea and high temperature. However, they can act as proper 'illnesses' in the following examples: sleeping sickness and yellow fever where they belong to the categories of 'infectious' and 'contagious' illnesses, respectively. Common collocations with 'illness' or 'disease' are: have an illness/disease, get an illness/ disease (those that you often have) and suffer from an illness/disease (in more formal contexts and with more serious diseases). Interestingly enough, with 'disorder', the usual collocation is have a disorder, not suffer from a disorder which makes it a separate category with restricted use. The verbs 'give' and 'have' are called light verbs, which means that the action is described by a nominal unit that follows them (Cattell, 1984: 2). Also, the verbs 'strike' and 'afflict' are to be stressed because thanks to them the noun has an agentive function - it does the action (Cruse, 1973: 11-23).

The example is: Cholera struck him. Some verbs define the nature of disease, e.g. die of AIDS provides the meaning of 'fatal illness', and contract flu provides the feature of 'infectious disease'. There are two types of verbs - those that provide negative meaning (as the abovementioned) and those that denote positive meaning, such as: relieve the pain, staunch bleeding, prevent malaria etc.

As to adjectives, we can differentiate among those that denote "nature of illness' such as congenital, mental, metabolic, 'severity' like slight/mild, moderate, severe/serious, fatal, then 'localization' such as pulmonary, cardiac, intestinal, 'duration' - acute, chronic, prolonged, 'extent' like partial, total, endemic, epidemic 'age' - infantile, juvenile, senile, 'cause' - viral, bacterial. Like verbs, they can determine the true meaning of illness', e.g. endemic tuberculosis; tuberculosis is a contagious illness. These studies have confirmed that all languages are identical at the level of deep structure, but in terms of surface levels they exhibit differences (Mićić, 2004: 441-

444). 
The fourth lexical feature of EMP is hyperonymy and hyponymy. Hyponymic relation, as a semantic category, implies the relationship between specific, narrow and general, wide lexical units. It means that meanings of specific lexical units must be included in the meanings of general lexical units. Thus certain hierarchical relationship is made between a wider term - hyperonym and the included term - hyponym.

The set of lexical units, hyponyms, of the same superior term are called cohyponyms and their interrelation is linear. One of the basic criteria for determining a hypoSofija nymic relationship is invariance. So, hyperonymy is created when the same component in a hyperonym is unspecified (illness), and in a hyponym it is specified (pulmonary illness). A determinant has a function of a localizer, it signifies part of the body in which illnesses are manifested. In terminological fund, hyponymy is, as a rule, multilinear, and alternative hyperonymic and hyponymic relations are made (Štasni, 2002: 252-255).

Specific characteristics of illness dictate the order of lexemes in hierarchy. The first line hyponym is general in nature, functioning as a hyperonym (illness); the second line hyponym is general, too (pulmonary illness); the third-line hyponym is more specific - a concrete example of illness (asthma); the fourth-line hyponyms are complex lexemes (cardiac asthma, bronchial asthma) where cardiac and bronchial are determiners of localisation; the fifth-line hyponyms are chronic asthma, allergic asthma, psychogenic asthma, where chronic, allergic, psychogenic represent causative Agents (Figure 1). From a lexicographic point of view, hyperonymy is extremely important, because a hyponym is most commonly defined via a hyperonym: pulmonary illness - asthma; asthma is a pumonary illness (Štasni, 2002: 257-259; Mićić, 2006: 271).

- allergic

- asthma

- hypogenic

- asthma

- bronchial

- asthma

- chronic

- asthma

- asthma

- pulmonary

- illness

- illness cardiac

- asthma

Figure 1. Hyperonymic and hyponimic relations of the term illness

Metaphors are also one of the lexical features of the language of medicine. There may be identified (1) the kinds of metaphors used to structure medical concepts and (2) the functions of metaphorical expressions in medical texts (catachretic, didactic and theory-constitutive). Of particular importance are didactic metaphors as they refer to doctor-patient communication. The dominant conceptual 
metaphor in American culture is that disease is an outrage and "Medicine is war". Fighting disease is emphasized rather than caring for sick patients. This metaphor entails that action is a virtue, doctors are fighters, technologies are weapons and disease is the enemy.

The language of medicine assigns physicians an active role and patients, by default, a passive role. Another major conceptual metaphor of biomedicine is "The body is a machine". According to this view, the individual is seen as the sum of the body's parts, e.g. "The heart is a pump", "The digestive system is plumbing", "The brain is a computer", "A cell is a machine", and "Cells contain machinery". In virtually every language and every culture body parts serve as metaphors. They come to stand for perceived physical or mental states, such as eat your heart out!, he hasn't a leg to stand on, it makes my blood boil, she gets under my skin, a gut reaction, get off my back!, or in your face - all based on associative meanings that attach to the respective body parts in English. Some of these associations extend across languages and across cultures (Fleischman, 2003: 484-488; Mićić, 2009 a: 125-127).

It is usually epidemics that are thought of as plagues. And these mass incidences of illness are understood as inflicted, not just endured (Sontag, 1990: 133). The disease is often experienced as a form of demonic possession - tumours are 'malignant' or 'benign', like forces - and many terrified cancer patients are disposed to seek out faith healers, to be exorcised (Sontag, 1990: 69). AIDS and cancer are two diseases that provide very illustrative metaphors. More than cancer, but rather like syphilis, AIDS seems to foster ominous fantasies about a disease that is a maker of both individual and social vulnerabilities (Sontag, 1990: 153).

\subsection{Discourse Features of EMP}

Medical writing style implies a certain degree of impersonality, avoidance of prolixity, exact description, fixed methods of reporting, hypothesising (Mc Morrow, 1998: 25), and conveying the impression of objectivity (Nash 1990). For example, "He was discharged home in good condition" is a common phrase, and it would be inappropriate to transform it into "They discharged him home in good condition".

Knowledge of the phraseology of the genre (i.e. a command of the semiprestructured phrases that occur in medical papers) will help students to understand and create meaning (Marco, 2000: 77). Medical jargon is full of sequences of words and idioms which may sound unusual in everyday speech. For example, the phrase "the patient complains of ..." has nothing to do with the patient "complaining", but means that the patient "presented with". Case reports follow strict conventions that determine the phrases used to describe a particular medical situation. For example, "The postoperative course was uneventful": the term "uneventful" cannot be literally translated. To change or ignore the standard phrases is to fail to adhere to the conventions of the target text, making it sound less professional and perhaps even compromising its scientific credibility (Berghammer, 2006: 43). Still worse, inaccuracies in medical translations may have serious clinical consequences (O’Neill, 1998: 70-71). Some authors have written about the struggle with English 
by non-nativespeakers. Benfield calls this weak appreciation of the conventions of discourse in English the 'English Language Burden' (ELB) (Benfield, 2007: 363).

\subsection{Languages for Medical Purposes (LMPs) Today}

In the last 30 years of the twentieth century, English has been rapidly exported from and imported into many languages through the dominant role of the U.S. in computer science and technology as well as medical technology. So, in addition to the Greco-Latin heritage there is knowing the current mix of standard English from all scientific and technological sources, including new eponyms, acronyms, abbreviations and trade names. Biochemistry, cell and molecular biology, immunology and bioengineering are the chief sources for the flood of new terms entering the medical dictionaries (McMorrow, 1998: 24-25). According to a July 24, 1995, article in US News and World Report, about 25,000 new English words are coined every year, of which $4 \%$ make it into dictionaries. The catching up with English goes on continually in native languages, by either finding adequate native words, borrowing from English, or adapting English words to native languages (sometimes poorly) (Segura 1998, 40).

As far as the Serbian language is concerned, there has still been no established and widely accepted language of medicine in medical publications. In earlier times, there used to be a tendency to use popular terms in medical articles. Today, there are no justifications for this, since those are publications of professionals for professionals (Slavković, 2004: 58). Still, when writing for a scientific journal, in the same context, it may happen that one Serbian author uses one term (e.g. rilising hormon), another may use oslobadjajući hormon and the third one may use liberin (Mićić, 2004: 31). Another feature is that Serbian medical terms have been either forgotten or rejected in favour of Greco-Latin terms predominantly used by Serbian doctors.

Finally, with the increasing influence of English as an international language of medicine, there have appeared numerous anglicized terms. Thus the Serbian medical language is a disorganized mixture of Greco-Latin and anglicized terms (Mićić, 2009a: 86). This also applies to other languages of limited diffusion. For example, Croatian medical terminology is mostly based on Latin, but recently English has had a strong influence on Croatian medical langauge at all language levels (Gjuran-Coha, in press).

\subsection{Medical Communication}

The Oxford English Dictionary tells us that the word 'communicate' comes from the Latin 'to impart, to share'. 'Communication' is imparting, conveying or exchanging ideas, knowledge, etc. (Figure 2).

- Reassurance

- Communication

- To form and maintain relationships

- To convey feelings

- To persuade

- To make decisions 
- To give information

- To alleviate distress

- To solve problems

Figure 2. Some purposes of communicating (Lloyd and Bor, 2006: 2-3)

The ability to communicate and interact effectively is a critical skill for all allied health professionals because of the many barriers and challenges unique to the profession (Hosley and Molle, 2006: 2). Clear, concise, accurate communication in any form is important in all areas of health care. This includes exchanges between health care professionals, such as chart notes and memos etc. in which there is responsibility for making sure that information was received and understood as it was intended (Hosley and Molle, 2006: 10-11).

There are five specific groups of professionals with whom health professionals must be able to communicate:

- coworkers/peers

- physicians

- managers/supervisors

- regulatory agency personnel

- referral professionals.

Each group is unique and comes with its own set of challenges (Hosley and Molle, 2006: 182-184).

\subsection{Technical/Medical Translation}

Successful, i.e. adequate, translation implies not only the knowledge of the Source Language (SL) and the Target Language (TL) but contrastive competence, using primarily semantic as well as formal correspondents but also words and structures other than the corresponding ones to render the same or similar meaning. In the former case, it is strictly literal translation in which the translator adopts a principled approach to the source text. There is no need to change the original mold. In the latter case(s), he takes a pragmatic approach. It is the question of free translations, adaptations, paraphrases, where the TL text is independent (Hlebec, 2009: 176-183).

The Language of Science and Technology (LST) is a register characterized by special(ist) terms and terminological combinations. The terms are associated with the explicitly and strictly defined concept about science and technology. Thus theirreferential function is expressed most, it predominates, other functions (e.g. expressive or aesthetic) being much less important. This allows a principled approach to translation implying more or strictly literal translation - transcription and transliteration of the terms.

\subsection{Language Proficiency Testing of Doctors}

In Europe, there may be imposed tougher language proficiency requirements for doctors who intend to work abroad, because of their inadequate language skills in a country's official language. There is a Professional Qualifications Directive but it is interpreted differently across Europe. For example, in Italy, there is a language 
assessment test post-registration. In Austria, doctors are subjected to scrutiny of a panel, in Cyprus the regulator conducts interviews while in Portugal the doctors discuss a video recording with a regulatory panel. In some countries like Ireland, Malta, Belgium, it is left to employers to gauge language proficiency or a test within the first six months of employment is required (Denmark). In Poland and Serbia, it is enough for doctors to provide written declaration that their level of Polish or Serbian is up to speed while in Luxembourg there are no language requirements unless doubts are raised about a doctor's linguistic skills. In the Czech Republic, written and oral tests are taken. The UK General Medical Council does not conduct language assessment because of prohibition in its regulatory framework. The council, together with 25 other European medical regulators comprise a group called Informal Network of Competent Authorities for Doctors and they issued a joint statement in 2010 asking for mandatory language testing in the interest of patient safety. Namely, there were cases in the UK of alleged malpractice with disastrous results by foreign doctor in the media (Villanueva, 2011: 321-322). In 2009, there was launched the sTANDEM project in Hungary, intended to create universal medical language test financed by the EU and to be implemented in the EU.

\subsection{LMPs - Future}

Today, it is clear that ESP represents a necessity and, in terms of its practical value, has a greater relevance than English for General Purposes. The English language of medicine has been well developed and standardized and should be taught at all world faculties. As far as Serbia and the neighboring countries are concerned, English for Medical Purposes courses have been much varied. There is a need to develop uniform standardized curricula.

Since the English language of medicine is highly developed, it should serve as a model for all nations as to how to build their languages of medicine. This is especially important since it has turned out that Greco-Latin terminology is no longer sufficient as a means of expressing modern medicine so all nations should build native medical terminologies and the language of medicine in their own languages. To achieve this goal, it is necessary to standardize national languages as a prerequisite for the existence of the language of medicine. For future purposes, it is necessary to organise programmes for LSP (including medical purposes) teacher education at philological faculties. They could be in the form of master and academic specialization programmes. Enormous development of medical science and practice, both basic and clinical, has led to numerous specialized and subspecialized branches that should be followed by an appropriate language.

The study of numerous specialized and subspecialized languages of medicine has been required by social circumstances. To further illustrate, molecular biology, genetics, quantum medicine as well as clinical branches, such as internal medicine, cardiology, surgery, endocrinology, dermatology and many others should be accompanied by specialized languages of medicine. Furthermore, the development of technology and pharmaceutical industry imposes the need for an adequate language to express it. All the above requires writing new pragmatic dictionaries. 
In this manner, native terminology of each language will be preserved and new terms, non-existent in the language in question, will be linguistically analyzed and thus enrich the given language. This will help to avoid the flood of anglicisms and other foreign terms which have been incorrectly used and do not mean anything in either the source or the target language. It is to be especially stressed that once these inappropriate, incomplete terms are used, they become nativized and almost impossible to correct. In order to avoid this, there should be the cooperation between language teachers and medical professionals. It is our opinion that only linguists who are trained in LSP are the ones who should teach LSP and language of medicine. Collaboration with experts in the field i.e. physicians, health professionals and particularly medical students who are taught the language of medicine will enable successful language teaching and provide adequate results expected by society.

\section{RESEARCH METHODS}

The researcher has used the descriptive analytical and quantitative methods as well as a questionnaire as a tool in the collection of relevant data and information in pursuing this paper. Population of this study is drawn exclusively from Khartoum College for Medical Sciences. The sample is the second class students of Medical Sciences at Khartoum College for Medical Sciences. A sample of (60) students was randomly selected for the questionnaire.

\section{FINDINGS AND DISCUSSION}

The researcher has used the questionnaire as a tool in the collection of data relevant to this study. The researcher has designed a questionnaire to answer the question" to extend English Language as International Medium can help in Learning Medical Sciences?" Among the second class students who study Medical Sciences to provide answers to the problems that encountered them. The tables below are going to illustrate what has been stated earlier.

This item tries to elicit information from the Medical students concerning their views about the role of English Language as International Medium for Learning Medical Sciences.

Table 1: The use of English language does not give input with clarity to Medical students.

\begin{tabular}{|l|l|l|l|l|}
\hline \multicolumn{1}{|c|}{ Parameters } & Frequency & \multicolumn{1}{|c|}{ Percent } & Valid Percent & $\begin{array}{c}\text { Cumulative } \\
\text { Percent }\end{array}$ \\
\hline Agree & 45 & $75 \%$ & $75 \%$ & $75 \%$ \\
\hline Neutral & 15 & $25 \%$ & $25 \%$ & $100 \%$ \\
\hline Disagree & 00 & $00 \%$ & $00 \%$ & \\
\hline Total & 60 & $100 \%$ & $100 \%$ & \\
\hline
\end{tabular}

Table (1) above shows that a vast majority of the respondents (75\%) Strongly agree and agree that the use of English language does not give input with clarity to 
Medical students. Only 00\% do not agree to that. This indicates that the use of English language does not give input with clarity to Medical students.

Table 2: The use of Arabic Medical Terms facilitates learning of Medical Sciences.

\begin{tabular}{|l|l|l|l|l|}
\hline Parameters & Frequency & Percent & Valid Percent & $\begin{array}{l}\text { Cumulative } \\
\text { Percent }\end{array}$ \\
\hline Agree & 50 & $83.3 \%$ & $83.3 \%$ & $83.3 \%$ \\
\hline Neutral & 10 & $00 \%$ & $00 \%$ & $100 \%$ \\
\hline Disagree & 00 & $16.7 \%$ & $16.7 \%$ & \\
\hline Total & 60 & $100 \%$ & $100 \%$ & \\
\hline
\end{tabular}

Table (2) above shows that a vast majority of the respondents (83\%) Strongly agree and agree that the use of Arabic Medical Terms facilitates learning of Medical Sciences. Only $00 \%$ do not agree to that. This indicates that the use of Arabic Medical Terms facilitates learning of Medical Sciences.

Table 3: The use of Arabic allows Medical students to relate what they already known to learning of Medical Sciences

\begin{tabular}{|l|l|l|l|l|}
\hline Parameters & Frequency & Percent & Valid Percent & $\begin{array}{l}\text { Cumulative } \\
\text { Percent }\end{array}$ \\
\hline Agree & 30 & $50 \%$ & $50 \%$ & $50 \%$ \\
\hline Neutral & 00 & $00 \%$ & $00 \%$ & $100 \%$ \\
\hline Disagree & 30 & $50 \%$ & $50 \%$ & \\
\hline Total & 60 & $100 \%$ & $100 \%$ & \\
\hline
\end{tabular}

Table (3) above shows that a vast majority of the respondents (50\%) Strongly agree and agree that the use of Arabic allows Medical students to relate what they already known to learning of Medical Sciences. Only 50\% do not agree to that. This indicates that the use of Arabic does not allow Medical students to relate what they already know to learning of Medical Sciences.

Table 4: Most students benefit from using Arabic in learning English language

\begin{tabular}{|l|l|l|l|l|}
\hline Parameters & Frequency & Percent & Valid Percent & $\begin{array}{l}\text { Cumulative } \\
\text { Percent }\end{array}$ \\
\hline Agree & 35 & $58.3 \%$ & $58.3 \%$ & $58.3 \%$ \\
\hline Neutral & 00 & $00 \%$ & $00 \%$ & $100 \%$ \\
\hline Disagree & 25 & $41.7 \%$ & $41.7 \%$ & \\
\hline Total & 60 & $100 \%$ & $100 \%$ & \\
\hline
\end{tabular}

Table (4) above shows that a vast majority of the respondents (58.3\%) Strongly agree and agree that most students benefit from using Arabic in learning English language. Only $41.7 \%$ do not agree to that. This indicates that most students benefit from using Arabic in learning English language. 
Table 5: The use of classical Arabic Equivalences for Latin and Greek Terms help a lot in understanding Medical Terms

\begin{tabular}{|l|l|l|l|l|}
\hline Parameters & Frequency & Percent & Valid Percent & $\begin{array}{l}\text { Cumulative } \\
\text { Percent }\end{array}$ \\
\hline Agree & 55 & $91.7 \%$ & $91.7 \%$ & $91.7 \%$ \\
\hline Neutral & 5 & $8.3 \%$ & $8.3 \%$ & $100 \%$ \\
\hline Disagree & 00 & $00 \%$ & $00 \%$ & \\
\hline Total & 60 & $100 \%$ & $100 \%$ & \\
\hline
\end{tabular}

Table (5) above shows that a vast majority of the respondents (91.7\%) Strongly agree and agree that the use of classical Arabic Equivalences for Latin and Greek Terms help a lot in understanding Medical Terms. Only 00\% do not agree to that. This indicates that the use of classical Arabic Equivalences for Latin and Greek Terms help a lot in understanding Medical Terms.

The data collected was analyzed in relation to the study hypothesis. The data was collected by questionnaire which had given to Medical students who do not know answers. Also analyzing the data collected from the questionnaire which had been given to Medical students exclusively drawn from Khartoum College for Medical Sciences. The population is second class students of Medical Science at Khartoum College for Medical Sciences. A sample of (60) students was randomly selected for the questionnaire.

The researcher has used the questionnaire as a tool in the collection of data relevant to this study. The researcher has designed questionnaire to identify the problems encountered Medical students who do not know the answers.

The marks obtained from the questionnaire for all participants were analyzed and compared statistically by using frequencies and percentages. The analysis showed that the highest percentage which is represented agree is estimated by (77\%) in contrast to the percentage of disagree which is estimated by $(8.34 \%)$ lesser than this one. Accordingly, this justifies that there is statistical difference in terms of Medical students' point of views that English Language as International Medium can play great role for Learning Medical Sciences.

\section{CONCLUSION}

After the comparing and calculating of the sub-hypotheses; we have found that the total number of the five sub-hypotheses percentage $(75 \%+83 \%+58.3 \%+91.7 \%)$ equal $(77 \%)$ which represents positive respond justifies that English Language as International Medium can play a great role for Learning Medical Sciences.

\section{REFERENCES}

Benfield, J. R. (2007). "Cardiothoracic Surgeons Divided By a Common Language", Ann Thorac Surg, 84: 363-364.

Berghammer, G. (2006). "Translation and the language(s) of medicine: Keys to producing a successful German-English translation", The Write Stuff, 15, 2, 40-44. 
Cattell, R. (1984). Composite Predicates in English, North Ryde, New South Wales: Academic Press Australia.

Coxhead, A. \& P. Nation (2001). "The specialised vocabulary of English for Academic Purposes", in: J. Flowerdew \& M. Peacock (eds.), Research Perspectives on English for Academic Purposes, 252-267. Cambridge: Cambridge University Press.

Cruse, D. (1973). "Some thoughts on Agentivity", Journal of Linguistics, 9, 11-23, Cambridge: MIT Press.

Dudley-Evans, T. \& M. J. St John (1998). Developments in English for Specific Purposes. A multi-disciplinary approach. Cambridge: Cambridge University Press.

Fleischman, S. (2003). "Language and Medicine", in: D. Schiffrin, D. Tannen and H. E. Hamilton (eds), The Handbook of Discourse Analysis, 470-502. Malden, MA, Oxford, UK, Victoria, Australia: Blackwell Publishing.

Gjuran-Coha, A. (in press). "An insight into the Croatian Language of Medicine", Serbian Archives of Medicine.

Hauenherm, E. (1998). "Sprachsystem und Sprachgebrauch in der kontrastiven lexicalischen Semantik", in: E. Weigand (ed.) Contrastive Lexical Semantics, Vol. 17, 139-162. Amsterdam/Philadelphia: John Benjamins Publishing Company.

Hlebec, B. (2009). Opšta načela prevodjenja. Beograd: Beogradska knjiga.

Hosley, J. and E. Molle. (2006). A Practical Guide to Therapeutic Communication for Health Professionals. St Louis: Elsevier, Inc.

Johns, A.M. \& T. Dudley-Evans. (1993). "English for Specific Purposes: International in Scope, Specific in Purpose", in: S. Silberstein (ed.), State of the Art TESOL Essays, 115-132. Bloomington, IL: Pantagraph Printing.

Jordan, R. R. (1997). English for Academic Purposes. A guide and Resource Book for Reachers. Cambridge: Cambridge University Press.

Lloyd, M. and R. Bor. (2006). Communication Skills for Medicine. Edinburgh, London, New York, Oxford, Philadelphia, St Louis, Sydney, Toronto: Churchill Livingstone.

Marco, M. J. C. (2000). "Collocational frameworks in medical research papers: a genre-based study", English for Specific Purposes, 19, 63-86.

McMorrow, L. (1998). "Breaking the Greco-Roman Mold in Medical Writing: the Many Languages of 20th Century Medicine", in: H. Fischbach (ed.), Translation and Medicine. American Translation Association Scholarly Monograph Series. Vol. X, 13-27. Amsterdam/Philadelphia: John Benjamins Publishing Company.

Micic, S. (2008). "The Role of Translation in Undergraduate Medical English Instruction', Iberica, 16, 169-182.

Micic, S. (2009). "A New Bilingual Dictionary for Medical Profession", American Journal of Translation Studies, Volume I, Number I, 24-37.

Mićić, S. (2009 a). Studije o jeziku medicine u engleskom i srpskom. Beograd: Beogradska knjiga. 
Mićić, S. (2006). "Engleski i srpski termini za bolesna stanja: interdisciplinarni pogled", Zbornik Matice srpske za filologiju i lingvistiku, XLIX/2, 267-275.

Mićić, S. (2004). Nazivi bolesti i poremećaja u engleskom i srpskom jeziku. Beograd: Beogradska knjiga. Sofija Mićić: Languages of Medicine - Present and Future

Mićić, S. (2011). 'Problems in Translating Modern English Medical Terms into Serbian', in: ELLSIIR/English Language and Literature Studies: Image, Identity, Reality Proceedings, Vol. 1, Beograd: Univerzitet u Beogradu, Filološki fakultet, 531-542.

Mićić, S., Marković, V. (2011). "Grčko-latinska terminologija kao osnova u savremenom engleskom I srpskom", Jezik struke. Izazovi perspektive. Zbornik radova, 837-844.

O’Neill, M. (1998). "Who Makes a Better Medical Translator: The Medically Knowledgeable Linguist or the Linguistically Knowledgeable Medical Professional? A Physician's Perspective", in: H. Fischbach (ed.) Translation and Medicine, ATA Scholarly Monograph Series, Vol. X, 69-80. Amsterdam/Philadelphia: Johns Benjamins Publishing Company.

Orr, T. (2002). "Introduction: The Nature of English for Specific Purposes", English for Specific Purposes TESOL Journal, 1-2.

Parkinson, J. (2000). "Acquiring scientific literacy through content and genre: a theme-based language course for science students", English for Specific Purposes, 19, 369-387.

Pilegaard, M. (2000). "Introduction", in: Hermes-Journal of Language and Communication Studies, Thematic Sections-Medical LSP, 25, 7-9.

Ruiz-Garrido, M.F., J.C. Palmer-Silveira and I. Fortanet-Gomez (2010). "Current trends in English for Professional and Academic Purposes", in: M. F. RuizGarrido, J.C. Palmer-Silveira and I. Fortanet-Gomez (eds) English for Professional and Academic Purposes, 1-8. Amsterdam-New York: Rodopi.

Segura, J. (1998). "Some Thoughts on the Spanish Language in Medicine", in: H. Fischbach (ed.) Translation and Medicine. American Translation Association Scholarly Monograph Series. Vol. X. Amsterdam/Philadelphia: John Benjamins Publishing Company, 37-48.

Slavković, V. (2004) „Neke naše zablude o jeziku medicinske struke",Medicinski časopisi i članci: drugi stručni sastanak - zbornik radova, Srpski arhiv za celokupno lekarstvo, posebno izdanje, 56-61.

Sontag, S. (1990). Illness as Metaphor and AIDS and its Metaphors. New York/London/Toronto/Sydney/Auckland: Anchor Books Doubleday.

Štasni, G. (2002). „Hiperonimijski i hiponimijski odnosi u medicinskoj terminologiji sa leksikološkog ileksikografskog stanovišta', u: Deskriptivna leksikografija standardnog jezika i njene teorijske osnove, 251-260. Novi Sad-Beograd: SANU, Matica Srpska, Institut za srpski jezik.

Trimble, L. (1985). English for Science and Technology, A Discourse Approach. Cambridge: Cambridge University Press.

Villanueva, T. (2011). "Europe contemplates stricter language proficiency testing of doctors", CMAJ, April 5, 2011, 183(6), 321-322. 
Wakabayashi, J. (1996). "Teaching Medical Translation", Meta, XLI, 3: 356-365.

Wood, A. (2001). "International scientific English: The language of research scientists around the world", in: J. Flowerdew \& M. Peacock (eds.), Research Perspectives on English for Academic Purposes, 71-83. Cambridge: Cambridge University Press.

Ypsilandis, G.S. and Z. Kantaridou (2007). "English for academic purposes: Case studies in Europe", Revista de Linguistica y Lenguas Aplicadas (2): 69-83. 